\title{
Farmers' Perception of Termite Infestation and Their Indigenous Management Practices in Abedengoro Resettlement Areas, Western Ethiopia
}

\author{
Temesgen Beyene* Oljira Kenea \\ Department of Biology, College of Natural and Computational Science, \\ Wollega University, Nekemte, Ethiopia
}

\begin{abstract}
This study is aimed to assess farmers' perception of termite infestation and their indigenous management practices in Abedengoro resettlement areas. Four termite hot spot rural resettled kebeles (lower Ethiopian administrative units) were selected purposively to include highly termite infested areas. Questionnaires were used to collect data from 240 respondents which account $3.5 \%$ of the total population those selected proportionally from the sample kebeles. Descriptive statistics was used to analyze the collected data. The results show that the local farmers' perception about termite infestation was very high. They reported that termites mostly damage crops, forest trees, and grazing land. However, the damage is serious to annual and biennial plants. Maize, sorghum and teff were reported to be the most infested crops among the crops produced in the study settings. The farmers also reported that termites that pose damage are prevalent year-round, but abundantly found in dry season. The farmers in study area knew termite infestation problems and indigenous management practices. Among the indigenous termite management practices reported, disturbing mound and suffocating mound with flood were the major indigenous termite management practices identified in the study setting. In conclusion, utilization of farmers' indigenous knowledge will not only promote ownership and sustainable use of intervention tools against termite pests but also has paramount importance in complementing ecologically friendly methods of termite control in an Integrated Termite Management in rural Ethiopia.
\end{abstract}

Keywords: Farmers perception, Resettlement, Termites, Termite infestation, Termite management

DOI: $10.7176 / \mathrm{JBAH} / 10-5-01$

Publication date:March $31^{\text {st }} 2020$

\section{INTRODUCTION}

Termites are the most problematic pests against plant communities and building infrastructure compared to others, in which 300 of them are considered to be pests among so far discovered species (Kumari et al., 2013). The potential of termites to damage and destroy agricultural crops, buildings and land escapes which may account to high economic loss in the world is becoming the main concern of study in the present days (Bong et al. 2012). Termites are able to exert this kind of damage with their indiscriminate species which estimated over 3000 species in all over the world (Engel et al, 2011).

The worldwide distribution of termites is due to their adaptation to high degree of resource specialization which enables them to be familiar to range of dietary, foraging and nesting habits. In this regard, subterranean termites are known as economically important species that encounter $80 \%$ loss in the world specifically to tropical, subtropical ecosystems and temperate region ( $\mathrm{Su}$ and Scheffran, 2002).Father more, termite distribution, diversity and abundance are influenced by climate that enable the existence of the different zoogeographical areas of the globe.

Africa accommodates the largest termite fauna in the world. The termite species richness in Africa is due to the friendly climatic conditions prevalent in the continent (Ahmed et al.2002). However, the abundance of termite in Africa is restricted by desert areas and at high altitude where low temperatures are found (Lee and Wood, 2002).

In East Africa, termites pose a major threat to agricultural crops, forestry seedlings, rangelands and wooden structures. In Ethiopia, the problem is most severe in the western parts of the country including Wollega area (Abdulahi et al. 2010). Because of population pressure and degradation of natural resources in Ethiopian highlands, high altitudinal mobility and agricultural resettlement in more fertile lowlands has become a common event in the country (Deressa et al., 2006). Resettlement is the phenomenon of population redistribution, either planned or "spontaneous" into new sites called resettlement sites or schemes (Rahmato, 2003). Termites are abundant and widely distributed in the low land of the country (Wood, 1991). Termite in Ethiopia induces negative impact interpreted in terms of economic as expenditure for damage, repair and preventive treatments cost. Nevertheless, an estimate of the annual losses caused by termite attacks is not clearly known. However, Wood, (1986) stated 60\% damage record due to termite.

Moreover, severity of termite damage to the western parts of the country on agricultural crops, range lands, forestry seedlings and wooden structures of rural houses, stores, fences and bridges are common reports (Abdurahman 2000). In this regard over $90 \%$ of this termite damage to agriculture, forestry and urban settings is 
attributed to members of the Macrotermitinae (Sileshi et al., 2009; Abdurahman et al, 2010).

Termite damage is also evident in Horo guduru-Wollega major districts specifically in Abedengoro districts low lands, where there are resettlements of Derge regime. In this district, termite population is vastly increasing as cultivation advances timely for in need of surplus product and construction purposes. This condition favors termite to aggressively attack crops, grazing, forest and construction till the present time.

In combating termite damage resettles use different synthetic chemicals, that they were given as supports from governmental and, none governmental organization for termite protection and boost production through varies devised techniques. Nevertheless, termite's damage continues to clear forest, grazing land, hamper production and damaging building. Moreover, the resettlement areas termite protection is remained over looked by researchers. Therefore, the presenet study was undertaken to assess farmers' perception of termite infestation and their indigenous management practices in Abedegoro resettlement areas in western Ethiopia.

\subsection{MATERIAL AND METHODS}

\subsubsection{The study area}

Abedengoro district (ADD) is one of the 21 districts located in Horo Guduru Wollega zone of Oromia Regional State, western Ethiopia with total land area of 109, 209 ha. The district capital, Tullu Wayu is located 567 kilometers from Addis Ababa and at about $40 \mathrm{~km}$ from Shambu, capital town of the zone. Agro-climatically, ADD is composed of three agro-ecological zones (AEZ): Dega (High altitude), Woyina Dega (mid altitude) and Kola (lowland). There were four high land, 11 mid (moderate) land and six kola (lowland) kebeles in ADD. The area exhibits a mono modal rain fall receiving rain during April to October. The annual rainfall ranges from 900-1800 millimeters and mean annual rainfall of about $950 \mathrm{~mm}$. The dry season is from November to March. The highest temperature is $34^{\circ} \mathrm{c}$ and the lowest is $18{ }^{\circ} \mathrm{c}$, with an average annual temperature about $21^{\circ} \mathrm{c}$. The topography of the area is mainly characterized by gentle slopes and few undulating hills steep/slopes and swamps. According to Agriculture and Development office of ADD (2018), the main land use patterns in the district is classified in to rain fed farm land which was about 46,753ha and irrigated land accounts 3425 ha. The same source indicated that natural forest and artificial forest covers 25,232 ha and 180 ha respectively, whereas grazing land covers 11,210 ha. The settlement area covers 7,381 ha.

Most of the farmers in the study area were able to identify the soil based on its color as red soil (Biyyoo Diimtuu) and black soil (Biyyoo Gurraacha). Based on texture, they categorized as clay (Biyyoo Suphee), loam, sandy (Biyyoo Cirrachaa) the reddish soil is dominant in all 21 kebeles of the district. The total rural population of ADD was (Male 12155, Female 1146) plus urban (male 2265, female 342). The livelihood in the area is mixed farming; major crops include maize, sorghum, sesame, peanut, teff, wheat, haricot bean, barley, finger millets, bean, chickpea, rice, cabbage, pea, sun flower and others. The cash crops are coffee, ginger, pepper and sesame. Shallot, pepper spices fruits and vegetables are onion, mango, banana, papaya, apple, potato, sugarcane among others.

\subsubsection{Research design}

Descriptive survey research was used to describe farmers' perception of termite infestation and management practices used to control the prompt problems. This type of research design is used for it is concerned with describing the characteristics of a particular issues (Kothari, 2004). Along with this research design mixed qualitative and quantitative research approach was used.

\subsubsection{Types and sources of data}

The study used primary data which are qualitative and quantitative in nature. Primary data were collected from respondents, Key Informants (KI) and Focus Group Discussion (FGD) on farmers' perception on termite infestation level and their indigenous management practices.

\subsubsection{Sampling techniques and sample size}

Among 11 districts of Horo Guduru Wollega zone, ADD was purposively selected for this study because almost all of the low land areas (kebeles) of the district were suffering from termite damage and hosting resettlement kebeles. Among the six low land kebeles of the districts, four kebeles were selected using simple random sampling techniques. Accordingly, kebele 15, 20, 24 and 25 were sampled to be included in the study.

Indeed, the target population of the area is homogenous (small holder resettled farming community) and engaging in similar agricultural production and farming system. Thus, small sample size was preferred for the study. As a result, 3.5\% of population was sampled which accounts for 240 respondents from 6,956 target population of the four sample kebeles. By applying proportionality sampling the sample size in each kebele was as presented in table 1 . 
Table 1. Number of sample respondents per kebele engaged in the study

\begin{tabular}{llll}
\hline Kebles & $\begin{array}{l}\text { No of House } \\
\text { Hold }\end{array}$ & $\begin{array}{l}\text { \% of house hold } \\
\text { from each kebele }\end{array}$ & No of respondents \\
\hline Mender 15 & 2575 & 3.5 & 90 \\
Mender 24 & 2009 & 3.5 & 70 \\
Mender 20 & 1555 & 3.5 & 54 \\
Mender 25 & 727 & 3.5 & 25 \\
Total & 6,956 & & 240 \\
\hline
\end{tabular}

Source: Abedengoro district Agricultural office, (2018)

Individual respondents were selected proportionally from among household heads of sample kebeles using systematic sampling method as

Where:

$$
I=\frac{N}{n}
$$

$\mathrm{I}=$ sample interval;

$\mathrm{N}=$ number of household heads per kebele

$\mathrm{n}=$ number of sample per kebele.

Then every $\mathrm{I}^{\text {th }}$ respondent was included in sample until the required individual obtained from respective sample kebele.

Six KI were selected by using judgment sampling method to include the very informed people about termite problem and management aspects. Moreover, four agriculture extension agents working in the sample kebeles and two agricultural experts from the district were selected. One FGD was administered with 12 people composed of one elder farmer; one trained farmer and one kebele administrative representative from each sample kebele and pulled together for discussion.

\subsubsection{Data Collection Tools and Procedures}

Since single data collection tools is believed to have limited adequacy and relevance to achieve the objectives of the study, different tools were employed to collect data to have better and adequate information for analysis. Thus, semi-structured (open-ended and closed-ended) questionnaire merely to collect primary data from respondents, indepth interview to collect data from key informants and discussion guide to collect data from FGD were used in the study. Data were also collected by personal observation using observation checklist.

The data from respondents were collected by enumerates who were trained by the researchers on how to approach the respondent and filling the questionnaires and the data collection tool were first prepared in English and later translated in to Afan Oromo to make it convenient to data collectors. However, the key informant interview and focus group discussion were administered by the researchers.

\subsubsection{Data analysis}

The collected data were sorted and analyzed using descriptive data analyzes statistics. The results presented using table, frequency and percentages. The data analysis was done using Statistical Package for Social Sciences (SPSSversion 20) software. Qualitative data obtained from interview and discussion were analyzed and described through concepts and opinions, by sorting out, grouping and organizing in order to supplement the results obtained from descriptive analysis

\subsection{Results and Discussion}

\subsubsection{Farmers' Perception of Termite Infestation}

From the entire surveyed small holder farmers $97.91 \%$ agreed that they recognized termites as a pest, while $2.09 \%$ of them fail to locate. These results revealed that most of the farmers in the study area knew termite as pest. In line with these results Debelo and Degaga (2015) reported that Ethiopian farmers from eastern part of the country were knowledgeable about the existence of termites in their crop fields. Concerning termite infestation status, 35.41\% of the farmers reported that termites infest mainly crops, Grass, and houses all together. However $20.17 \%, 20.83 \%$, and $15.6 \%$ the farmers said termite infest only crops, grasses, and houses respectively. The views of KI and FGD also indicates termite's infest and damage all crops, chop grasses, damage houses and other materials where they inhabit and are general feeders in the study settings. 
Table 2. Farmers' perception of termites as pest

\begin{tabular}{llll}
\hline & Response & \multicolumn{2}{c}{ Respondents } \\
\cline { 3 - 4 } & & Frequency & Percentage \\
\hline \multirow{2}{*}{ Termite recognized as pest } & Yes & 235 & 97.91 \\
& No & 5 & 2.09 \\
& Total & 240 & 100 \\
\hline \multirow{3}{*}{ Termites damage } & Crops & 70 & 29.17 \\
& Grasses & 50 & 20.83 \\
& House & 35 & 15.6 \\
& All & 85 & 35.41 \\
& Total & 240 & 100 \\
\hline
\end{tabular}

\subsubsection{Termite as a pest of crops}

Some three crops were reported by farmers as most susceptible to termite infestation (Figure 1). Among them, maize $33.33 \%$ the most susceptible followed by teff $27.08 \%$ and sorghum $22.92 \%$. Others $15.95 \%$ were found less susceptible. The incident of sorghum damage on crop fields is observed less than maize and teff. Because, sorghum may be protected from termite damage due to its role as a reservoir of termite predatory ants (Sekamatte et al., 2003). This result is supported by KI and FGD in that maize is the most known produced crop among others and its estimated loss report was greater than one quintal per hectare (key- informants).

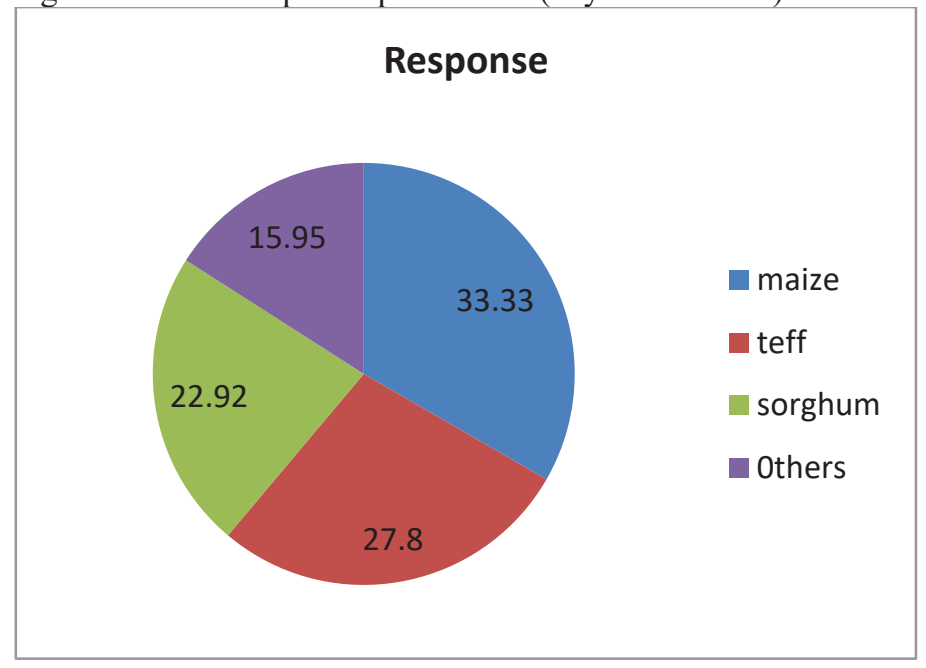

Figure1.Farmers' Perception of crops severely damaged by termites in Abedengoro resettlement villages in 2018 . 1.2.3. Termites as pest of grazing land and forest

With regard to grazing land and forest tree damage, $75 \%$ of the farmers agree that damage in tree is common and $25 \%$ of them replied grasses. The farmers also reported the consequence of forest tree damage by the termites in the study area in which the highest cause was deforestation (50\%) followed by running water depreciation $(25 \%)$ and soil degradation $(20.83 \%)$ in that order. However few of the farmers $(3.17 \%)$ fail to distinguish the impact of termite effect on their ecosystem.

Table 3. Termites as a pest of grazing land and forest

\begin{tabular}{llcc}
\hline & Category & $\begin{array}{c}\text { Respondents } \\
\text { Frequency }\end{array}$ & Percentage \\
\hline \multirow{3}{*}{ Termites damage } & Grazing land & 60 & 25 \\
& Forest trees & 180 & 75 \\
& Total & 240 & 100 \\
\hline \multirow{3}{*}{$\begin{array}{l}\text { Consequence } \\
\text { forest damage }\end{array}$} & Soil degradation & 50 & 20.83 \\
& Deforestation & 120 & 50.00 \\
& Running water depreciation & 60 & 25.00 \\
& & & \\
& I don't know & 10 & 3.17 \\
\hline
\end{tabular}

The current study also shows that forest trees are the most susceptible to termite attack than grasses. Deforestation was the most reported consequence of forest damage by termites followed by soil degradation and depreciation of running water. It was reported by KI and FGD that termite's damage majority of the trees. However, there is a difference in terms of tolerance to termite attack.

The preference of termites for this tree may be due to its water content as supported by (Loko et al, 2014). 
As a result, the soil degradation is estimated as $10 \%$ in the study area. (District agricultural office, 2017) In similar occasion, FGD report indicates that Eucalyptus tree species grow long down to drain water from the most ground to its bark where the termite species harbor and extract fluid (Plate 3)

\subsubsection{Season favoring termite infestation}

Table 4 shows favorable time period for termite activities. The farmers most frequently reported $(31.25 \%)$ that termites are most abundant in dry season with the least report between wet and dry season (13.92\%). This result is supported by KI and FGD, they perceive that termite's damage is more apparent during dry time. The result is in harmony with findings of Logan et al., (1990) and Nyeko and Olubayo (2005) that indicate termite is more prevalent in dry season than during the periods of regular rainfall.

Table 4. Favorable time for termite abundance

\begin{tabular}{lcc}
\hline & \multicolumn{2}{c}{ Respondents } \\
\cline { 2 - 3 } Category & Frequency & Percentage \\
\hline Summer season & 60 & 25.00 \\
Dry season & 75 & 31.25 \\
Between Winter and Dry & 31 & 13.92 \\
All the time & 74 & 30.83 \\
Total & 240 & 100 \\
\hline
\end{tabular}

1.2.5. Farmers' Perception of Susceptible and Resistant Plants to Termite Infestation

In the assessment of plant age $42.67 \%$ respondents replied that annual plants are easily attacked while $31.67 \%$ of the farmers viewed biennial plants and $26.66 \%$ respondent answer that termite damage more perennial plants. In supporting this Haris (1961) and Roonwal (1979), state the damages being more serious in young plants of about one or two year of age.

With regard to plant stage of development vulnerability to termite infestation, $38 \%$ respondents viewed that all seed, seedling, flowering stages of plants were easy to be damaged. On the other hand, $28.3 \%, 27.9 \%$ and $5.8 \%$ agreed that the damage can happen to seed, seedling and flowering stage of development respectively (Table 5).

Table 5. Susceptible and resistant plant sage to termite damage

\begin{tabular}{clcc}
\hline & Category & \multicolumn{2}{c}{ Respondents } \\
\cline { 3 - 4 } & & Frequency & Percentage \\
\hline Susceptible plants & Annual plants & 100 & 41.67 \\
& Biennial plant & 76 & 31.67 \\
& perennial Plants & 64 & 26.66 \\
& Total & 240 & 100 \\
\hline Susceptible age to termite & Seed & 68 & 28.3 \\
damage & Seedling & 67 & 27.9 \\
& Flowering & 14 & 5.8 \\
& At all age & 91 & 38 \\
& Total & 240 & 100 \\
\hline
\end{tabular}

\subsubsection{Farmer perceptions of termite management practices}

Termite management endeavor follow traditional termite identification by the local people. The results indicate the presence of two locally known termites; called 'usually observed' and 'immigrant' type. Accordingly, $41.66 \%$ respondents say the usually observed type, and others $45.84 \%$ replied the immigrant and few $12.5 \%$ respondents do not differentiated the two types of termites (table 6). This kind of local naming agree with the local names given to the two types of termites Werrartu (meaning 'invaders' in Afan Oromo) and Marimartu (meaning 'common to the area' in Afan Oromo (Hirpa et al, 2012). The Marimartu have mounds and stay in some places whereas, the Werrartu are non-mound forming and migratory type.

Table 6. Termite traditional category in Wollega, Ethiopia

\begin{tabular}{llll}
\hline & Category & Respondents & \\
\cline { 2 - 4 } Local name & & Frequency & Percentage \\
\cline { 2 - 4 } of termites & Usually appeared & 100 & 41.66 \\
& Immigrants & 110 & 45.84 \\
& I don't know & 30 & 12.5 \\
& Total & 240 & 100 \\
\hline
\end{tabular}

\subsubsection{Termite resistant plant species utilized by farmers}

The severity of termite damage to different construction impose farmers to look for termite resistant plant species. .To this aspect, $41.25 \%$ of the respondents replied that they knew Cyzyum guniems, Ficus Species, Cordia africana and Trunus africana which called Badessa, Harbuu, Waddessa and Hoomii in Afan Oromo as resistant plants, however, 16.66\%, 16.25\%, 13.33\% and 12.5\% respondents view Ficus Species, Cyzyum guniems, Cordia africana and Trunus africana respectively (Table 7). 
Table 7. Termite resistant plants identified by the farmers with their local names

\begin{tabular}{|c|c|c|c|c|c|}
\hline \multirow{7}{*}{$\begin{array}{l}\text { Resistant } \\
\text { identified }\end{array}$} & \multirow{7}{*}{ plants } & Scientific Names & $\begin{array}{l}\text { Local Name } \\
\text { (Afan Oromo) }\end{array}$ & $\begin{array}{l}\text { Respondents } \\
\text { Frequency }\end{array}$ & Percentage \\
\hline & & Cyzyum guniems & Badessa & 39 & 16.25 \\
\hline & & Ficus Species & Harbu & 40 & 16.66 \\
\hline & & Kordia Africana & Waddessa & 32 & 13.33 \\
\hline & & Trunus Africana & Hoomii & 30 & 12.5 \\
\hline & & All & & 99 & 41.25 \\
\hline & & Total & & 240 & 100 \\
\hline
\end{tabular}

The farmers reported that Ficus Species, Cyzyum guniems, Cordia africana and Trunus africana which called Badessa, Harbuu, Waddessa and Hoomii in afan Oromo are the major resistant plants in the study settings. KI and FGD supplement the result in that these plants are used for construction purpose for they resist termite damage. In supporting this, Owusu et al., (2008) state that, some plants are resistant to termite damage, indeed, their exudate (natural extract) repel termite and that is why people use those plants for construction.

\subsection{Suppressing termite population in the mound}

The stress due to termite damage imposes farmers to control termite culturally with their indigenous knowledge. Having this, respondents were asked how they manage termite mounds and found that $99.17 \%$ said that they disturb mound to remove Queen and others $8.33 \%$ respond not using mound disturbance. Concerning termite control by flooding $66.67 \%$ respondents replied they use flooding the termite mound to suppress termite population. However, it is found that majority of the respondents use the indigenous knowledge of termite management practice like sealing with chopped removed weeds (79.17\%), smoking the mound to suffocate termite $(68.75 \%$,), adding pepper dissolved with ash $(85.42 \%$,), irrigating with Tela and Areke Residue (tela) (83.33\%,), goat urine and hot animal dung $(95.83 \%)$ (Table 8$)$

Table 8. Traditional termite mound management practices in Abedengora in 2018.

\begin{tabular}{llll}
\hline Category & Response & Respondents & \\
\cline { 2 - 3 } & & Frequency & Percentage \\
\hline \multirow{2}{*}{ Flooding termites' mound } & Yes & 160 & 66.67 \\
& No & 80 & 33.33 \\
\hline Sealing with Chopped removed weeds & Total & 240 & 100 \\
& Yes & 50 & 20.83 \\
Smoking the mound to suffocate termite & No & 190 & 79.17 \\
& Total & 240 & 100 \\
Disturbing mound to remove queen & Yes & 75 & 31.25 \\
& No & 165 & 68.75 \\
Adding pepper dissolved with ash & Total & 240 & 100 \\
\cline { 2 - 3 } & Yes & 220 & 99.17 \\
& No & 20 & 8.33 \\
& Total & 240 & 100 \\
\cline { 2 - 3 } & Yes & 35 & 14.58 \\
& No & 205 & 85.42 \\
Irrigating with Tela and Areke Residue & Total & 240 & 100 \\
& Yes & 40 & 17.66 \\
& No & 200 & 83.33 \\
& Total & 240 & 100 \\
\cline { 2 - 4 } & Yes & 10 & 4.17 \\
& No & 230 & 95.83 \\
& Total & 240 & 100 \\
\hline
\end{tabular}

In the study of indigenous knowledge traditionally used to suppress termite population in the mound in surveyed area reveals that majority of the farmers are practicing to disturb mound to remove Queen and use flooding termite mound thereby suppressing the termite population. Views of KI and FGD supplementing the result in such a way that those traditional termite management practices are practiced. This is in line with a research finding by Akutse et al, (2012) in Ghana, several indigenous methods including wood ash, sand, toads and shell/scallop of tortoise are used by farmers to prevent and control termites.

\subsubsection{The use of termite's predator}

Regarding the use of termite's predators, $91.3 \%$ of respondents agree with the use of termite predators, while $8.8 \%$ of them do not know the termite predators. Out of the identified predators, $46.7 \%$ are birds and $38.3 \%$ ants. However, $15 \%$ claim the presence of other predators (table 9). 
Table 9. Prevalent predators

\begin{tabular}{clcc}
\hline & & \multicolumn{2}{c}{ Respondents } \\
\cline { 3 - 4 } & Category & Frequency & Percentage \\
\hline \multirow{2}{*}{ Presence of termite } & Yes & 219 & 91.35 \\
predators of termites & I do not Know & 21 & 8.75 \\
& Total & 240 & 100 \\
\hline \multirow{3}{*}{ Types of predators } & Birds & 112 & 46.7 \\
& Ants & 92 & 38.3 \\
& Other & 36 & 15 \\
& Total & 240 & 100 \\
\hline
\end{tabular}

Source; computed from observation of (2018).

The study on prevalence of predator in study area reveals that most of farmers aware that birds and ants are the most known termites' predators. This, finding is supported by KI and FGD in that they familiar to those aforementioned predators. They also added that, worms and other arthropods which they fail to name living in the soil are observed foraging termites.

\subsection{CONCLUSIONS}

Results showed that the local farmers are well aware of termite as pest with the most infested and susceptible crop reported by the farmers being maize than teff, sorghum and other crops. The Farmers perceive and use several ways of mitigating termite damage. Among the indigenous termite management practices, results underline that the farmers relay on disturbing mound by digging to exclude termite queen, flooding termite mounds, sealing of mound with chopped removed weeds, adding pepper dissolved with ash, and salt, irrigating with tela and areke residue (atela), got urine mixed with hot animal dung to cause suffocation that might induce termite removal from their farm. Therefore, using farming community indigenous knowledge has a great potential to complement nonchemical and ecologically friendly methods of termite control programs in an Integrated Termite Management programs in rural Ethiopia.

\section{Competing interests}

The authors have read the manuscript and declared that no competing interests exist.

\section{Authors' contributions}

TB participated to the study design, conducted data collection, analysis and interpretation and drafted and revised the manuscript. OK involved in designing the study, revised the manuscript and has given approval of the version to be published. All authors read and approved the final manuscript.

\section{ACKNOWLEDGMENTS}

We are grateful to Wollega University for provision of financial support to conduct this research. Abedengoro district agricultural office generalist, Agricultural extension experts of the four kebeles are also greatly acknowledged.

\section{Author details}

1,2 Department of Biology, Wollega University, P. O. BOX 395, Nekemte, Ethiopia

\section{Reference}

Abdurahman A, Abraham T, Mohammed D (2010). Importance and Management of Termites in Ethiopia. Pest Manage. J. Ethiop. 14:1-20.

Abdurahman, (2000). Termites are structural pests in Ethiopia. Report of the UNEP/FAO/ Global IPM Facility Termites Biology and Management workshop. Geneva, Switzerland

Ahmad, M. and Akhtar, M.S. (2002). Catalogue of the termites (Isoptera) of the oriental region, Pakistan J. Zool. 2:1-86

Akutse KS, Owusu EO, Afreh-Nuamah K (2012). Perception of farmers' management strategies for termites' control in Ghana. J. Appl. Bio sci., 49: 3394- 3405

Bong J C F, King P J H, Ong K H and Mahadi N M. (2012). Termite assemblages in oil palm plantation in Sarawak, Malaysia. Journal of Entomology, 9: 68-78.

Engel, M.S. (2011). Family-group names for termites (Isoptera), redux. Zoo Keys, (148), 171.

Harris, W.V., 1970. An introduction to Malayan termites. Malay. Nat. J., 12: 20-32.

Kothari R. C. 2004. Research Methodology: Methods and Techniques. Second Edition, New Age International (P) Limited, Publisher. New Delhi

Loko. Laura Estelle. (2017) Journal of Ethno biology and Ethno medicine 13:64DOI 10.1186/s13002-017-0187-2 
Owusu EO, Akutse KS, Afreh-Nuamah K, (2008). Effect of some traditional plant components on the control of termites, Macrotermes spp. (Isoptera: Termitidae). African Journal of Science and Technology (AJST) Science and Engineering Series Vol. 9, No. 2, pp. 82 - 89.

Sekamatte MB, Latigo OM, Smith AR (2003). Effects of maize- legume intercrops on termites damage to maize, activity of predatory ants and maize yield in Uganda. Ugandan J. Crop Protectn., 22:653:662.

SPSS Inc. (2001) SPSS 11.0 Syntax Reference Guide: Englewood Cliffs, NJ: Prentice Hall.

Wood TG, Sands WA (1991). The role of termites in ecosystems. In: MV Brian (Ed.): Production Ecology of Ants and Termites, Cambridge, UK: Cambridge University Press, 245-292management programs.

Deressa W, Ali A, Berhane Y. (2006) Review of the interplay between population dynamic and malaria transmission in Ethiopia. Ethiop J Health Dev, 20: 137-144.

Rahmato, D. (2003) Resettlement in Ethiopia, The Tragedy of Population Relocation in the 1980s, Forum of Social Studies 2003, Addis Ababa.

Debelo DG, Degaga EG. (2015). Farmers' knowledge, perceptions and management practices of termites in the central rift valley of Ethiopia. Afr. J. Agric. Res.10:3625-3635. 